\title{
SISTEM INFORMASI ADMINISTRASI KEUANGAN SISWA PADA SMA NEGERI 1 MOYO HULU BERBASIS WEB
}

\author{
Febrianti $^{1)}$, Rodianto ${ }^{2 *}$, Nurlalily ${ }^{3)}$ \\ 1,2,3) Teknik Informatika Universitas Teknologi Sumbawa \\ Email: rodianto@uts.ac.id
}

\begin{abstract}
Abstaksi: Sistem Administrasi Keuangan di Sekolah Menengah Atas Negeri 1 Moyo Hulu masih dilakukan secara manual baik dalam hal transaksi maupun rekap data. Sehingga memperlambat di dalam proses pembayaran, pencatatan dan rekap pembayaran. Hal ini menyebabkan proses-proses yang terkait dengan pembayaran belum berjalan secara optimal. Penelitian ini bertujuan untuk mengetahui sistem yang berjalan dalam proses transaksi maupun rekap data di SMA Negeri 1 Moyo Hulu. Sehingga dapat dibangun suatu sistem informasi administrasi keuangan siswa menggunakan metode Prototype dalam pengembangan sistemnya yang meliputi tahapan-tahapan komunikasi, perencanaan secara cepat, pemodelan perancangan secara cepat, pembuatan prototype, penyerahan sistem. Sedangkan pengumpulan data dilakukan dengan cara observasi, wawancara, studi pustaka. Pemodelan sistem yang digunakan adalah bahasa pemodelan UML (Unified Modelling Language) dan berbasis web dengan bahasa pemrograman PHP (Hypertext Preprocessor) dimana Xampp sebagai web server dan Mysql sebagai databasenya. Pengujian perangkat lunak dilakukan melalui pengujian black-box.
\end{abstract}

Kata Kunci : Sistem Informasi, Administrasi Keuangan, Prototype, UML (Unified Modeling Language).

Abstract: The Financial Administration System at Public Senior High School 1 Moyo Hulu is still done manually, both in terms of transactions and data recapitulation. Thus, it slows down in the payment process, recording and recapping payments. This has resulted in processes related to payment not running optimally. This study aimed to determine the system that runs in the transaction process and data recap at Public Senior High School 1 Moyo Hulu, so that a student financial administration information system can be built by using the Prototype method in developing the system which includes communication stages, fast planning, fast design modeling, prototyping, and system submission. Meanwhile, data collection was carried out by means of observation, interviews, literature study. The modeling system used was the UML (Unified Modeling Language) and web-based modeling language was done with the PHP (Hypertext Preprocessor) programming language where Xampp is the web server and Mysql is the database. Software testing was done through black-box testing.

Keywords: Information System, Financial Administration, Prototype, UML (Unified Modeling Language).

\section{PENDAHULUAN}

Administrasi keuangan merupakan salah satu bagian penting dalam institusi pendidikan, karena semua aktifitas pengelolaan keuangan yang berhubungan dengan pencatatan pemasukan dan pengeluaran pembiayaan berbagai kegiatan siswa mulai dari administrasi pembayaran SPP, Pembayaran organisasi siswa, Pembayaran daftar ulang, dan Pembayaran Koperasi Siswa. Seluruh kegiatan administrasi keuangan ini dilakukan oleh pihak tata usaha sekolah bagian keuangan yang mengelola data keuangan serta menyimpannya dalam bentuk pembukuan keuangan.

Sekolah Menengah Atas Negeri 1 Moyo Hulu adalah suatu lembaga pendidikan negeri yang berdiri pada tanggal 10 September tahun 2003 yang beralamat di Jalan Raya Sumbawa BesarSemamung, Kecamatan Moyo Hulu, Kabupaten Sumbawa. Seiring bertambahnya waktu, SMA Negeri 1 Moyo Hulu mengalami perkembangan yang signifikan dari segi jumlah siswa. Perkembangan ini menuntut pihak tata usaha sekolah untuk mengelola data keuangan siswa sehingga dapat memproses data yang semula konvensional menjadi terkomputerisasi. Hal ini dilakukan untuk mempercepat kinerja, efisiensi dalam administrasi siswa serta dapat memberikan informasi keuangan secara akurat.

Bagian administrasi keuangan siswa sering mengalamai permasalahan yaitu seperti dalam pengelolaan data pembayaran siswa, pembuatan surat-surat serta dalam pengolahan data yang belum terintegritas dengan baik sehingga datadatanya belum tersusun secara rapi dapat menyebabkan terlambatnya pembuatan laporan serta sulitnya mendapatkan informasi keuangan dalam waktu yang cepat. Pengolahan data administrasi keuangan siswa dilakukan dengan cara ditulis tangan atau sering disebut dengan pembukuan, kemudian disimpan dalam berkasberkas dilemari penyimpanan. Permasalahan lain yang kemudian timbul adalah terjadinya penumpukan berkas yang menyebabkan kerusakan, serta lamanya waktu yang dibutuhkan untuk mencari data karena banyaknya berkas yang disimpan serta seringnya siswa yang menghilangkan bukti pembayaran.

Berdasarkan uraian permasalahan di atas, maka diperlukan sebuah aplikasi berbasis web sebagai fasilitas untuk membantu pengelolaan administrasi keuangan siswa agar lebih efektif dan efisien mulai dari proses administrasi hingga pembuatan laporan keuangan siswa. Oleh karena 
itu, penulis mencoba membangun "Sistem Informasi Administrasi Keuangan Siswa Pada SMA Negeri 1 Moyo Hulu Berbasis Web" Sistem informasi ini akan dibangun menggunakan bahasa pemrograman php dan databasenya dibuat dengan menggunakan bahasa pemograman mysql dengan menggunakan server xampp, dengan harapan dapat menyimpan data keuangan siswa dalam jumlah yang lebih besar.

\section{Tujuan Penelitian}

Adapun tujuan dari penelitian ini yaitu merancang dan membangun sebuah sistem informasi keuangan siswa berbasis web untuk membantu meningkatkan kualitas pelayanan pembayaran, memudahkan siswa dalam melakukan kegiatan pembayaran, serta membantu bagian keuangan dalam mendata, mengontrol, dan memonitoring keuangan siswa tersebut.

\section{LANDASAN TEORI}

Tinjauan Pustaka

Selama ini telah banyak penelitian yang mengkaji tentang aplikasi-aplikasi terkait sistem informasi administrasi keuangan salah satunya penelitian yang berjudul Pembangunan Sistem Informasi Administrasi Pembayaran Siswa Madrasah Aliyah Ma'arif Pacitan [1].

Saat ini proses pengelolaan administrasi pembayaran keuangan siswa di Madrasah mereka melakukan peneitian tersebut dengan tujuan mempermudah karyawan yang terdapat pada bagian keuangan. Saat ini proses pengelolaan administrasi pembayaran keuangan siswa di Madrasah Aliyah Ma'arif Pacitan masih bersifat konvensional dimana pencatatan data dilakukan ke dalam buku besar karena proses dapat menyita waktu, sering terjadi kekeliruan dan penyimpanan data masih berupa arsip. Sehingga menyebabkan kurang efektif dan efisien.

Aplikasi Pembayaran Administrasi Siswa Pada SMK Al Falah Songgom Brebes Dengan Visual Basic, dimana pada penelitian tersebut yang bertujuannya untuk menghasilkan sebuah Sistem administrasi keuangan siswa yang dapat membantu petugas keuangan dalam mengatasi banyak pembukuan yang didalamnya terdapat banyak jenis pembukuan sebagai acuan pengadministrasiaannya, guna untuk mempercepat kinerja pengguna sistem untuk dapat mengelola data keuangan dengan menginput, menyimpan dan mencetak data sesuai kebutuhan untuk dijadikan laporan [2].

\section{Dasar Teori \\ Sistem}

Sistem adalah sekumpulan elemen yang saling terkait atau terpadu yang dimaksudkan untuk mencapai suatu tujuan. Sebagai gambaran jika dalam sebuah sistem terdapat sebuah elemen yang tidak memberikan manfaat dalam mencapai tujuan yang sama maka elemen tersebut dapat dipastikan bukanlah bagian dari sistem [3].

\section{Sistem Informasi}

Sistem informasi adalah cara-cara yang diorganisasi untuk mengumpulkan, memasukkan dan mengelola serta menyimpan data, dan caracara yang diorganisasi untuk menyimpan, mmengelola, mengendalikan, dan melaporkan informasi sedemikian rupa sehingga sebuah informasi dapat mencapai tujuan yang telah ditetapkan [4].

\section{Administrasi Keuangan \\ Administrasi keuangan sekolah adalah langkah pengolahan keuangan sekolah yang dimulai dari penerimaan hingga bagaimana keuangan yang digunakan dipertanggungjawabkan secara obyektif dan sistematis. Langkah tersebut sangat penting untuk diperhatikan, sebab pembiayaan merupakan sarana vital yang akan mempengaruhi keberlangsungan proses pendidikan di suatu sekolah [5].}

\section{PHP}

PHP adalah singkatan dari "Hypertext Prepocessor" adalah salah satu bahasa pemrograman skrip yang dirancang untuk membangun aplikasi web. Ketika dipanggil dari web browser, program yang ditulis dengan $P H P$ akan di-parsing didalam web server oleh interpreter PHP diterjemahkan ke dalam dokumen HTML, yang selanjutnya akan ditampilkan kembali ke web browser, karena pemrosesan program PHP dilakukan dilingkungan web server, $P H P$ dikatakan sebagai bahasa sisi server (server-side). Oleh sebab itu, seperti yang telah dijelaskan sebelumnya, kode PHP tidak akan terlihat pada saat user memilih perintah "view Source" pada web browser yang digunakan [6].

Metode Pengembangan Perangkat Lunak 
Dalam melakukan perancangan sistem yang akan dikembangkan dapat mengunakan metode prototype. Metode ini cocok digunakan untuk mengembangkan sebuah perangkat yang akan dikembangkan kembali. Metode ini dimulai dengan pengumpulan kebutuhan pengguna, dalam hal ini pengguna dari perangkat yang dikembangkan adalah peserta didik. Kemudian membuat sebuah rancangan kilat yang selanjutnya akan dievaluasi kembali sebelum diproduksi secara benar [7].

Berikut adalah tahapan dalam metode prototype:



Gambar I. Metode Pengembangan Prototype (Pressman, 2012)

a. Komunikasi

Pada tahapan ini peneliti melakukan komunikasi atau wawancara langsung dengan bendahara, untuk mengetahui masalah yang ada pada SMA Negeri 1 Moyo Hulu. Dimana peneliti menganalisis untuk melihat komponen yang dipakai seperti sistem yang sedang berjalan serta mendokumentasikan aktifitas sistem informasi meliputi input, pemrosesan data, output, serta penyimpanan dokumen. Dalam tahap ini pengguna sistem atau pihak keuangan siswa yang nantinya akan mengelola sistem menjelaskan kepada peneliti tentang sistem yang ingin dicapai.

b. Perencanaan secara cepat

Setelah mendapatkan dan mengetahui masalah yang ada, maka tahap selanjutnya peneliti menganalisis kebutuhan perangkat keras, kebutuhan perangkat lunak, kebutuhan pengguna dan kebutuhan data untuk membangun suatu sistem.

c. Pemodelan Perancangan secara cepat

Setelah mendapatkan serta mengetahui seluruh kebutuhan yang diperlukan dalam melakukan pembuatan sistem, maka selanjutnya dilakukan pembuatan prototype Data. Tahap awal yaitu perancangan sistem menggunakan teknik UML. Kemudian tahap kedua yaitu melakukan perancangan data. Dan terakhir perancangan interface.

\section{d. Pembuatan Prototype}

Setelah prototype yang dibangun telah selesai kemudian akan dilakukan proses coding menggunakan IDE sublime text dengan menggunakan bahasa pemprograman PHP dengan framework CodeIgniter sebagai kerangka kerja dan database Mysql. kemudian dilakukan pengujian sistem, hal ini dilakukan untuk memastikan bahwa perangkat lunak yang telah dibuat dapat digunakan dengan baik dan sudah layak pakai atau perlu disempurnakan lagi. Dalam penelitian ini akan digunakan pengujian terhadap prototype Data dengan menggunakan metode pengujian Black-box testing lunak mencoba apakah semua fungsi berjalan sesuai prosedur yang ditentukan, jika testiing sudah benar maka program boleh digunakan.

e. Penyerahan Sistem.

Tahap akhir yaitu penyerahan aplikasi yang dibuat untuk melakukan evaluasi jika terdapat kekurangan dan memberikan umpan balik untuk pengembangan selanjutnya.

\section{Flowmap}

Flowmap adalah bagan- bagan yang mempunyai arus yang menggambarkan langkahlangkah penyelesaian suatu masalah. Flowmap merupakan cara penyajian dari suatu algoritma Flowmap atau bagan alir adalah bagan yang menunjukan aliran di dalam program atau prosedur sistem secara logika. Flowmap ini berfungsi untuk memodelkan masukan, keluaran, proses maupun transaksi dengan menggunakan simbol-simbol tertentu [8].

\section{Unified Modelling Language (UML)}

Unified Modeling Language (UML) adalah salah satu standar bahasa yang banyak digunakan di dunia industri untuk mendefinisikan requirement, membuat analisa dan desain, serta menggambarkan arsitektur dalam pemrograman berorintasi objek. pada UML terdiri dari 13 (tiga belas) macam diagram yang dikelompokkan dalam 3 (tiga) kategori.

Unified Modeling Language (UML) adalah bahasa pemodelan untuk sistem atau perangkat lunak yang berparadigma berorientasi objek. Pemodelan (modeling) sesungguhnya digunakan untuk penyederhanaan permasalahan yang kompleks sedemikian rupa sehingga lebih mudah dipelajari dan dipahami.[9]. 


\section{Pengujian Software}

Black box testing adalah menguji perangkat lunak dari segi spesifikasi fungsional tanpa menguji desain dan kode program. Pengujian dimaksudkan untuk mengetahui apakah fungsifungsi, masukan, dan keluaran dari perangkat lunak sesuai dengan spesifikasi yang dibutuhkan. Pengujian kotak hitam dilakukan dengan membuat kasus uji yang bersifat mencoba semua fungsi dengan memakai perangkat lunak apakah sesuai dengan spesifikasi yang dibutuhkan. Kasus uji yang dibuat untuk melakukan pengujian black box testing harus dibuat dengan kasus benar dan kasus salah [10].

\section{METODOLOGI PENELITIAN Metode Penelitian}

Adapun metode penelitian ini menggunakan 2 metode yaitu metode penelitian kualitatif yang bersifat deskriptif dan metode pengembangan perangkat lunak. Metode kualitatif adalah penelitian yang dilakukan untuk mengetahui nilai variabel mandiri, baik satu variabel atau lebih (independen) tanpa membuat perbandingan, atau penghubungan dengan variabel yang lain [11]. Sedangkan metode pengembangan perangkat lunak yang digunakan dalam skripsi ini adalah metode Prototype Data karena model ini lebih memperhatikan kebutuhan sistem pemakai dan secara keseluruhan akan mengacu kepada kepuasan user [12].

\section{Metode Pengumpulan Data}

Adapun prosedur pelaksanaan dalam pengumpulan data adalah sebagai beriku :

a. Observasi

Metode pengumpulan data yang dilakukan melalui pengamatan langsung atau peninjauan secara cermat dan langsung di SMA Negeri 1 Moyo Hulu.

b. Wawancara

Wawancara adalah metode pengumpulan data yang dilakukan melalui tatap muka dan tanya jawab antara peneliti dan narasumber. Menurut Nasution, (2018) Wawancara terstuktur adalah wawancara yang telah diketahui informasi apa yang akan digali oleh peneliti, sehingga telah disiapkan daftar pertanyaan secara sistematis sesuai pedoman wawancara. Sedangkan wawancara tidak tersturktur adalah wawancara yang dilakukan secara bebas, artinya peneliti tidak menggunakan pedoman wawancara, sehingga tidak ada daftar pertanyaan yang spesifik hanya berupa poin-poin saja. Pada penelitian ini, penulis melakukan wawancara secara tidak terstruktur kepada Bendahara SMA Negeri 1 Moyo Hulu guna mengumpulkan informasi yang dibutuhkan oleh peneliti.

c. Studi Pustaka

Studi pustaka dilakukan untuk meneliti referensi atau literatur yang dalam penelitian skripsi. Adapun referensi atau literature pendukung dalam penelitian skripsi ini barupa buku "Pengenalan Sistem Informasi Edisi Revisi Karya Abdul Kadir Tahun 2014 Yang Diterbitkan ANDI, Yogyakarta".

2. Metode Pengembagan Perangkat Lunak

Berikut ini tahapa-tahapan dalam pengembangan perangkat lunak menggunakan metode prototype:

a. Komunikasi

Pada tahapan ini peneliti melakukan komunikasi atau wawancara langsung dengan bendahara, Dimana peneliti menganalisis untuk melihat komponen yang dipakai seperti sistem yang sedang berjalan serta mendokumentasikan aktifitas sistem informasi meliputi input, pemrosesan data, output, serta penyimpanan dokumen.

b. Perencanaan secara cepat

Setelah mendapatkan dan mengetahui masalah yang ada, maka tahap selanjutnya peneliti menganalisis kebutuhan perangkat keras, kebutuhan perangkat lunak, kebutuhan pengguna dan kebutuhan data untuk membangun suatu sistem.

c. Pemodelan Perancangan secara cepat

Setelah mendapatkan serta mengetahui seluruh kebutuhan yang diperlukan dalam melakukan pembuatan sistem, maka selanjutnya dilakukan pembuatan prototype Data. Tahap awal yaitu perancangan sistem menggunakan teknik UML. Kemudian tahap kedua yaitu melakukan perancangan data. Dan terakhir perancangan interface.

d. Pembuatan Prototype

Setelah prototype yang dibangun telah selesai kemudian akan dilakukan proses coding menggunakan IDE sublime text dengan menggunakan bahasa pemprograman PHP dengan framework CodeIgniter sebagai kerangka kerja dan database Mysql. kemudian dilakukan pengujian sistem, hal ini dilakukan untuk memastikan bahwa perangkat lunak yang 
telah dibuat dapat digunakan dengan baik dan sudah layak pakai atau perlu disempurnakan lagi. Dalam penelitian ini akan digunakan pengujian terhadap prototype Data dengan menggunakan metode pengujian Black-box testing lunak mencoba apakah semua fungsi berjalan sesuai prosedur yang ditentukan, jika testiing sudah benar maka program boleh digunakan.

e. Penyerahan Sistem.

Tahap akhir yaitu penyerahan aplikasi yang dibuat untuk melakukan evaluasi jika terdapat kekurangan dan memberikan umpan balik untuk pengembangan selanjutnya.

\section{Alat dan Bahan Penelitian}

Adapun alat dan bahan yang dibutuhkan dalam penelitian yaitu, kebutuhan perangkat dan kebutuhan data. Kebutuhan perangkat yang digunakan berupa perangkat keras(hardware), perangkat lunak (software) dan kebutuhan pengguna(user) dengan hak aksesnya sesuai dengan kebutuhan penelitian yang dilakukan. Sedangkan untuk kebutuhan data yang digunakan berupa data-data yang berkaitan dengan penelitian yang dilakukan.

\section{Alur Penelitian}

Adapun alur penelitian dapat dilihat pada gambar berikut :

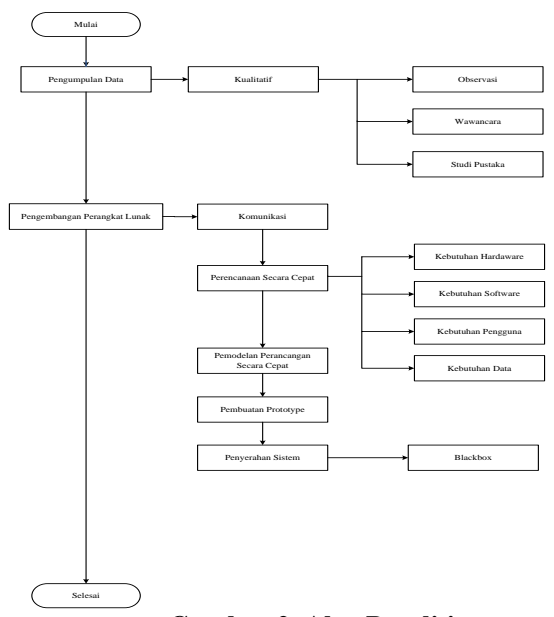

Gambar 2. Alur Penelitian

\section{HASIL DAN PEMBAHASAN}

Alur Kerja Sistem Berjalan

Berdasarkan hasil pengumpulan data yang peneliti lakukan melalui wawancara terhadap proses pembayaran keuangan siswa dilakukan oleh siswa SMA Negeri 1 Moyo Hulu menggambarkan bahwa sistem yang sedang berjalan pada kegiatan pembayaran tersebut masih mengalami banyak kendala, baik secara pelayanan maupun secara administrasi. Oleh karena itu, dari hasil analisis yang telah dilakukan peneliti dapat digambarkan alur kerja atau flowmap yang berjalan pada sistem saat ini sebagai berikut :

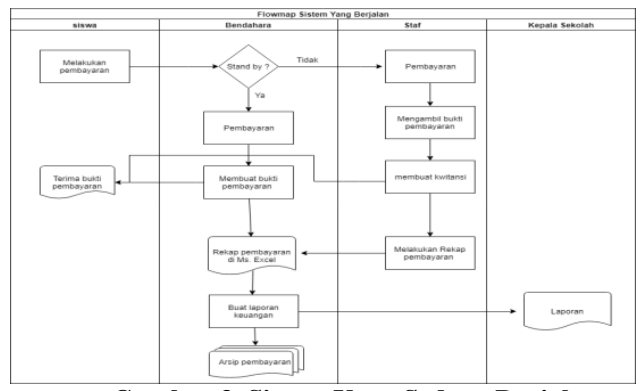

Gambar 3. Sistem Yang Sedang Berjalan

\section{Kerja Sistem Yang Diusulkan}

Berdasarkan hasil analisis terhadap sistem yang sedang berjalan dan hasil pengumpulan data melalui wawancara yang telah dilakukan terhadap kegiatan pembayaran oleh siswa di SMA Negeri 1 Moyo Hulu, kemudian peneliti menganalisis untuk sistem yang diusulkan untuk memperbaharui dan memperbaiki sistem yang sudah ada sesuai tujuan yang ingin dicapai. Adapun gambaran alur kerja atau flowmap pada sistem yang diusulkan sebagai berikut :

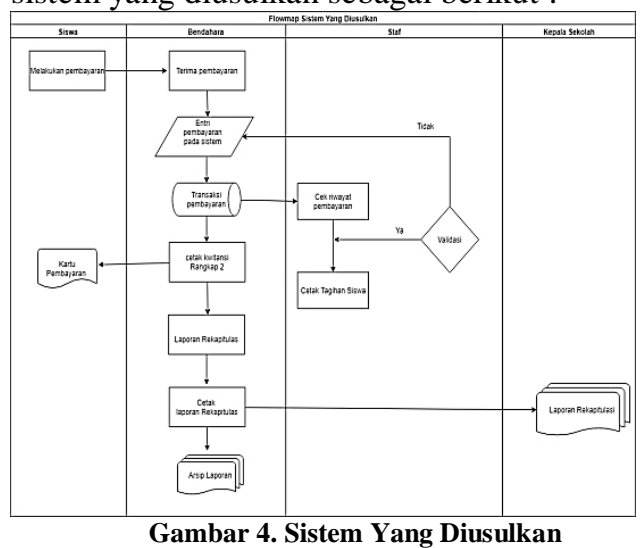

\section{Use Case Diagram}

Berikut adalah use case diagram dari sistem informasi administrasi keuangan siswa pada SMA Negeri 1 Moyo Hulu yang dibuat untuk mengetahui hubungan langsung antar user dengan sistem, yaitu sebagai berikut : 


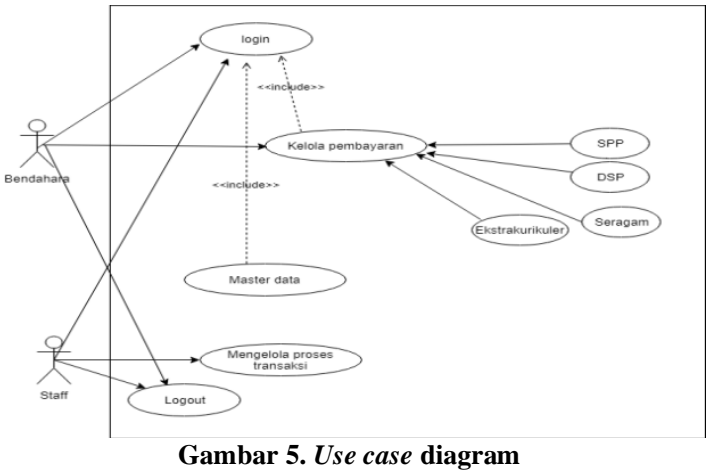

\section{Activity Diagram}

Berikut adalah Activity diagram dari Sistem Informasi Administrasi Keuangan Siswa pada SMA Negeri 1 Moyo Hulu Berbasis Web yang menggambarkan alur kerja sistem yang akan dibangun yaitu sebagai berikut :

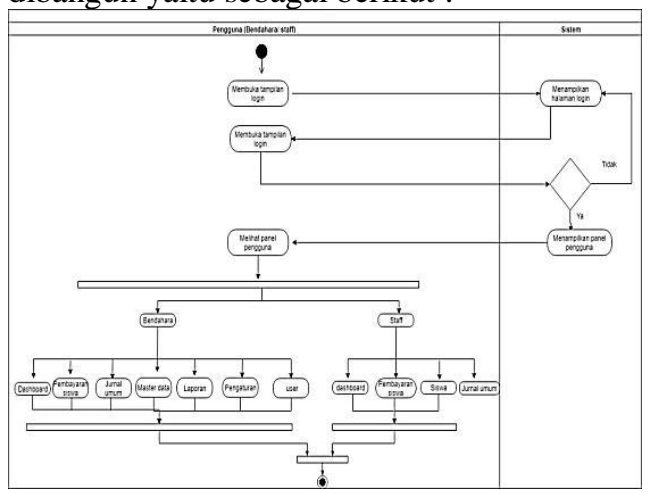

Gambar 6. Activity Diagram

\section{Sequence Diagram}

Pada sequence diagram login ini menggambarkan objek dan pendiskripsian waktu serta pesan-pesannya yang dibutuhkan untuk pengguna agar dapat masuk ke dalam sistem keuangan siswa tersebut. Adapun hasil perancangan yang telah peneliti buat sebagai berikut :

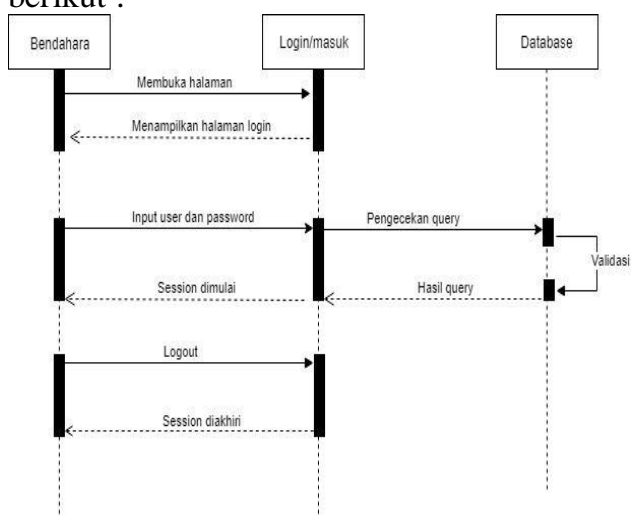

Gambar 7. Sequence Diagram

\section{Class Diagram}

Class diagram ini mendiskripsikan perancangan tentang bagaimana stuktur sistem keuangan siswa pada SMA Ngeri 1 Moyo Hulu dibangun berdasarkan atribut dan method. Adapun perancangan yang telah peneliti buat sebagai berikut :

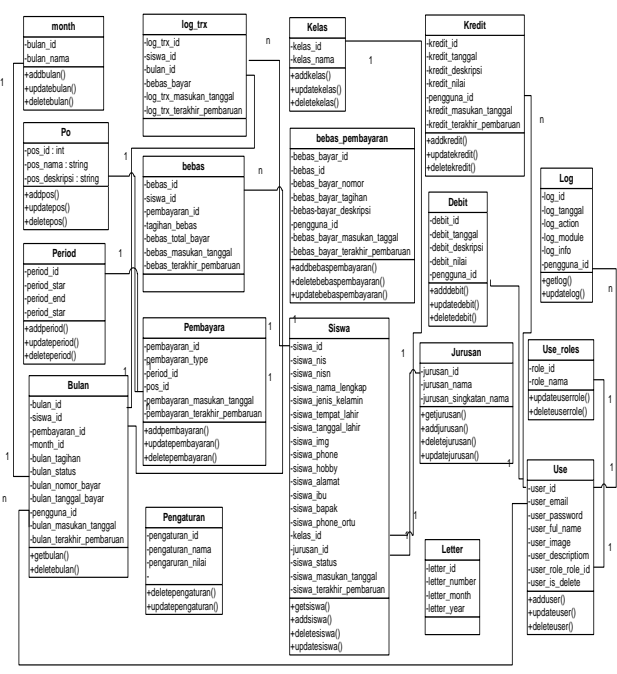

Gambar 8. Class Diagram

\section{Perancangan User Interface}

Berikut ini adalah perancangan user interface dari Sistem Informasi Keuangan Siswa Pada SMA Negeri 1 Moyo Hulu Berbasis Web, yaitu sebagai berikut :

1. Rancangan Interface Form Login Adapun rancangan interface form login, sebagai berikut :

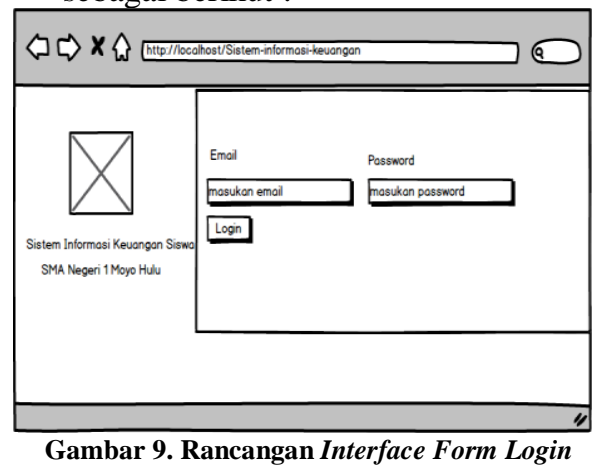

2. Rancangan Interface Halaman Dashboard Pada Admin

Adapun perancangan tampilan dashboard pada sistem keuangan siswa SMA Negeri 1 Moyo Hulu sebagai berikut : 


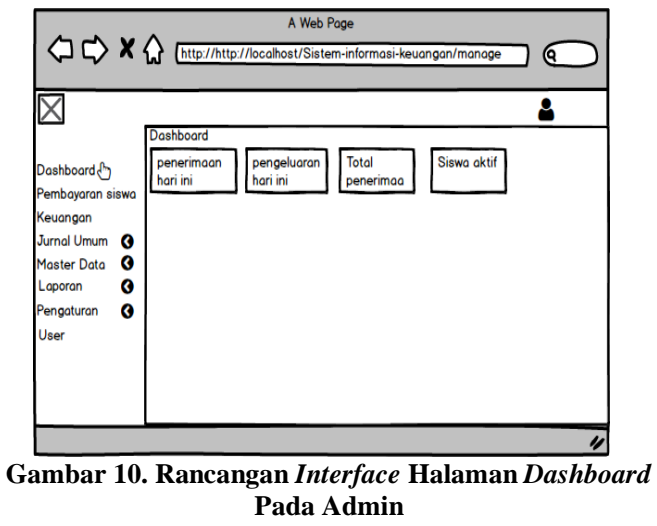

3. Rancangan Interface Halaman Dashboard Staff

Adapun rancangan interface halaman sebagai berikut:

\section{Pengujian Aplikasi}

Berikut adah tabel pengujian blackbox berdasarkan Sistem Informasi Administrasi :

Tabel 1. Pengujian

\begin{tabular}{|c|c|c|c|}
\hline $\begin{array}{c}\text { Aksi } \\
\text { Aktor }\end{array}$ & $\begin{array}{c}\text { Yang } \\
\text { Diharapkan }\end{array}$ & $\begin{array}{c}\text { Pengam } \\
\text { atan }\end{array}$ & $\begin{array}{c}\text { Kesimpu } \\
\text { lan }\end{array}$ \\
\hline $\begin{array}{l}\text { Memas } \\
\text { ukkan } \\
\text { email } \\
\text { dan } \\
\text { passwo } \\
\text { rd } \\
\text { sesuai } \\
\text { data. }\end{array}$ & $\begin{array}{l}\text { Muncul } \\
\text { tampilan } \\
\text { menu } \\
\text { utama } \\
\text { sesuai hak } \\
\text { akses user. }\end{array}$ & $\begin{array}{l}\text { Tampila } \\
\mathrm{n} \text { Login }\end{array}$ & sesuai \\
\hline $\begin{array}{c}\text { Data } \\
\text { Koson } \\
\text { g }\end{array}$ & $\begin{array}{l}\text { Muncul } \\
\text { pesan } \\
\text { "Please fill } \\
\text { out this } \\
\text { Nama } \\
\text { Data" }\end{array}$ & $\begin{array}{l}\text { Tampil } \\
\text { halama } \\
\mathrm{n} \\
\text { login }\end{array}$ & sesuai \\
\hline $\begin{array}{c}\text { Input } \\
\text { NIS }\end{array}$ & $\begin{array}{l}\text { Muncul } \\
\text { tampilan } \\
\text { tabel } \\
\text { tagihan } \\
\text { sesuai data. }\end{array}$ & $\begin{array}{l}\text { Tampila } \\
\mathrm{n} \\
\text { halama } \\
\mathrm{n} \\
\text { pembay } \\
\text { aran } \\
\text { siswa }\end{array}$ & sesuai \\
\hline
\end{tabular}

\section{KESIMPULAN DAN SARAN Kesimpulan}

Dari hasil pembuatan sistem keuangan siswa SMA Negeri 1 Moyo Hulu berbasis web ini, dapat disimpulkan bahwa peneliti telah melakukan analisis dan perancangan terhadap sistem yang kemudian menjadi landasan dalam

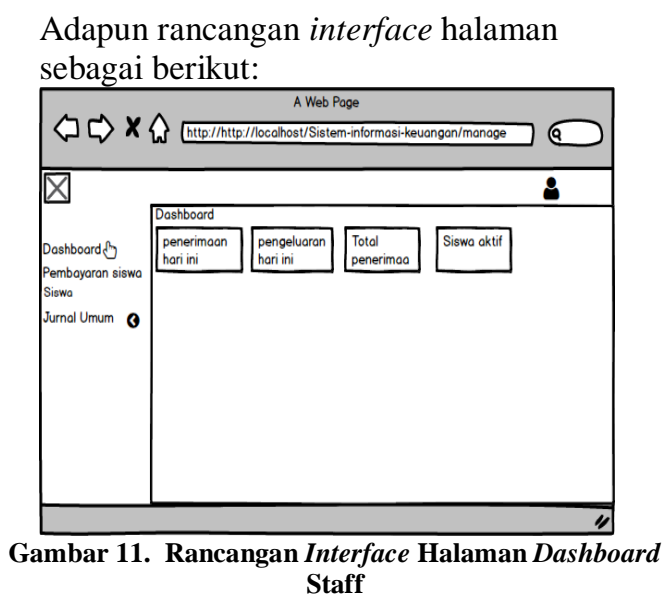

membangun sistem tersebut. Dalam membangun sistem berbasis web ini, peneliti menggunakan bahasa pemograman PHP, Framework CodeIgniter, serta database MySQL. Sistem keuangan siswa SMA Negeri 1 Moyo Hulu berbasis web ini dapat dijalankan melalui PC Bendaharan dan Staf sesuai hak akses masing-masing pengguna. Dengan demikian, sistem tersebut dapat membantu berlangsungnya kegiatan pembayaran yang dilakukan oleh siswa SMA Negeri 1 Moyo karena sistem pembayaran yang sudah lebih terstruktur, rapi, dan mudah untuk menvalidasi rekap keuangan mahasiswa.

\section{Saran}

Sistem informasi keuangan siswa SMA Negeri 1 Moyo Hulu ini masih jauh dari kesempurnaan, sehingga saran dari penulis kedepannya adalah :

1) Untuk penelitian selanjutnya, jika ada yang ingin melakukan penelitian

dengan objek yang sama dapat menghasilkan aplikasi yang lebih baik lagi. Seperti ditambahkan aplikasi SMS Gateway kepada wali murid ataupun fitur mengirim pesan interaktif secara online lainnya yang lebih canggih sehingga wali murid dapat mengetahui secara langsung perkembangan atau kendala dalam pembayaran siswanya.

2) Diharapkan juga pada penelitian selanjutnya dapat menambah fitur-fitur baru yang mungkin masih belum terdapat pada penelitian ini sehingga didapatkan 
hasil yang berbeda dan lebih baik dari penelitian ini.

3) Disarankan pada aplikasinya untuk menerapkan tutorial / panduan pengenalan fitur-fitur yang disediakan sehingga dapat mempermudah penggunaan aplikasi bagi pengguna yang awam terhadap fungsi fitur aplikasinya sehingga tanpa harus pengembang aplikasi yang menjelaskannya.

\section{DAFTAR PUSTAKA}

[1] Syahbana, A. (2012). Pembangunan Sistem Informasi Administrasi Pembayaran Siswa Madrasah Aliyah Ma'arif Pacitan. Speed-Sentra Penelitian Engineering dan Edukasi, 5(3).

[6] Anhar, S. T. (2010). Panduan Menguasai $P H P \&$ \& SQL Secara Otodidak. Jakarta: Mediakita.

[7] Roger S, Pressman. 2012. Rekayasa Perangkat Lunak (Pendekatan Praktisi) Edisi 7 ; Buku 1. Andi: Yogyakarta.

[8] Ladjamudin, Al Bahra Bin. 2006. Analisis dan Desain Sistem Informasi.Yogyakarta: Graha Ilmu.

[9] S, Rosa A,. \& M. Shalahuddin. 2018. Rekayasa Perangkat Lunak Terstruktur dan Berorientasi Objek. Bandung: Informatika.

[10] Rosa A.S. \& M. Shalahuddin. 2011. Modul Pembelajaran Rekayasa Perangkat Lunak. Bandung : PT. Modula
[2] Al'Amin, M., \& Mukholik, M. (2015). Aplikasi Pembayaran Administrasi Siswa Pada SMK Al Falah Songgom Brebes dengan Visual Basic. Jurnal Teknik Informatika dan Sistem Informasi, 1(3).

[3] Kadir, A. (2014). Pengenalan sistem informasi edisi revisi. Penerbit Andi.

[4] Krismiaji. (2015). Sistem Informasi Akuntansi. Yogyakarta.

[5] Gumilar, S. K. Y., Suryatiningsih, \& Muhammad, W. 2017. Aplikasi Berbasis Web Pengelolaan Keuangan Sekolah Study Kasus MA Persis Tarogong Garut. E-Proceeding of Applied Science ISSN :2442-5826, 3(2), 661-674. 